\title{
Effects of light, agar, activated charcoal, and culture medium on the germination and early development of Dendrobium seedlings
}

\author{
José Carlos Sorgato $^{{ }^{*}}$, Jackeline Schultz Soares ${ }^{2}$, Cláudia Roberta Damiani ${ }^{3}$, Luan Marlon Ribeiro ${ }^{1}$ \\ ${ }^{1}$ Federal University of Grande Dourados, College of Agrarian Sciences, Dourados, 79.804-970, Mato Grosso do Sul, \\ Brazil \\ ${ }^{2}$ State University of Mato Grosso do Sul, Natural Resources Department, Dourados, 79.804-970, Mato Grosso do \\ Sul, Brazil \\ ${ }^{3}$ Federal University of Grande Dourados, College of Biological and Environmental Sciences, Dourados, 79.804-970, \\ Mato Grosso do Sul, Brazil
}

*Corresponding author: josesorgato@ufgd.edu.br

\begin{abstract}
The objectives of this study were to determine the optimal light conditions, agar concentration, and quantity of activated charcoal in asymbiotic media to improve the in vitro seed germination rate and early seedling development of the epiphytic orchids Dendrobium nobile Lindl. and Dendrobium phalaenopsis Fitzg. Two independent experiments with complete randomized designs were conducted. (1) Treatments were arranged in a split-plot scheme. Seeds in each sub-plot were exposed to one of four light conditions (dark, white fluorescent, red fluorescent + white fluorescent, or red fluorescent) and grown in one of four types of culture media (MS: Murashige and Skoog, 1/2 MS: half strength MS, K: Knudson C, and VW: Vacin and Went media). (2) Treatments were arranged in a $4 \times 5 \times 5$ factorial scheme (four types of culture media: $\mathrm{MS}, 1 / 2 \mathrm{MS}, \mathrm{K}$, and $\mathrm{VW}$; five concentrations of agar: 0.0 , 2.0, 4.0, 6.0, or $8.0 \mathrm{~g} \mathrm{~L}^{-1}$; and five concentrations of activated charcoal: $0.0,1.5,3.0,4.5$, or $6.0 \mathrm{~g} \mathrm{~L}^{-1}$ ). The highest germination rates and early seedling development were observed 45 days after seeding in the presence of white light for $D$. nobile and red + white light for $D$. phalaenopsis in MS and $1 / 2 \mathrm{MS}$ culture media. Based on the findings of the present study, the use of MS and $1 / 2 \mathrm{MS}$ culture media solidified with 4.0-8.0 $\mathrm{g} \mathrm{L}^{-1}$ of agar and without activated charcoal is recommended for the optimal propagation of seeds and seedlings of these Dendrobium species.
\end{abstract}

Keywords: orchids, ornamental species, asymbiotic germination, PAR, gelling agent.

Abbreviations: D_continuous darkness; CP_chlorophyll propagules; K_ Knudson C culture medium (1946); MS_Murashige and Skoog (1962) culture medium; 1/2 MS_Murashige and Skoog (1962) culture medium at half the salt concentration; VW_Vacin and Went (1949) culture medium; NS_non-germinated seeds; \%G_germination rate (\%); NTW_no triple-wash (type of suspension washing); TW_triple-wash (type of suspension washing); R_red fluorescent lamp; WF_white fluorescent lamp; RW_red fluorescent lamp + white fluorescent lamp.

\section{Introduction}

In vitro culture techniques have been widely used to propagate orchids (Suzuki et al., 2010). The asymbiotic germination of orchid seeds has been performed since the early 20th century, when Knudson (1922) reported the successful germination of orchids using aseptic culture medium. Seed germination varies according to the specific nutritional requirements of each species and may differ at the different stages of development (Stewart and Kane, 2006; Paul et al., 2012; Silva et al., 2015). The proper choice of medium for in vitro seeding is, therefore, one of the main factors ensuring the success of asymbiotic culture techniques. Regarding the in vitro seeding of the genus Dendrobium, Silva et al. (2015) reported that the four types of culture media most commonly used are Murashige and Skoog (MS; Murashige and Skoog, 1962), 1/2 MS (half strength MS), Knudson C (K; Knudson, 1946), and Vacin and Went
(VW; Vacin and Went, 1949). Aside from the effects of the type of culture medium on germination, it is also important to consider the physical state of the medium, as the diffusion of nutrients to the propagated plant material increases or decreases according to the concentration of the gelling agent used (Faria et al., 2012). In addition, activated charcoal can also be used to further enrich the culture media as it has the capacity to adsorb toxic substances that are present in the medium or formed through the oxidation of phenolic compounds during the in vitro culturing process (Faria et al., 2012). However, in addition to the uptake of toxic substances, activated charcoal can also unfavorably absorb and retain vitamins, nutrients, and growth regulators, depending on the concentration of the charcoal used (Guson et al., 2012; Cid and Teixeira, 2014). 
Another important factor in asymbiotic seed germination is the presence of light (Silva et al., 2015). Orchid seed germination is differentially influenced by light (Arditti and Ernst, 1984; Silva et al., 2015), and it is universally accepted that the light requirements of orchids vary under natural conditions and according to the habitat of each species. Thus, the seeds of epiphytic orchids are theoretically expected to require the presence of light, while those of terrestrial species are expected to need darker conditions to germinate. The different responses to growing conditions, however, are often species-specific, regardless of the growth habit (Kauth et al., 2008). Some authors have reported that seed germination in several species of terrestrial orchids is inhibited by the presence of light (Stoutamire, 1974; Stewart and Kane, 2006; Godo et al., 2010). Thus, it is generally accepted that the symbiotic and asymbiotic germination of terrestrial orchid seeds occurs most commonly under continuous darkness (Kitsaki et al., 2004; Yamazaki and Miyoshi, 2006; Lee et al., 2007). However, as several authors have observed, seeds from some epiphytic species are able to germinate in both the presence and absence of light in vitro (Arditti and Ernst, 1984; Dutra et al., 2009; Tsutsumi et al., 2011).

Moreover, in addition to the effects of photoperiod on germination, some studies have analyzed the effects of different wavelengths on the germination, growth, and development of plants cultured in vitro. However, relatively few studies to date have reported on the morphophysiological effects of different light conditions on orchid plants.

Therefore, the objectives of the present study were to determine the optimal conditions (light, agar concentration, and activated charcoal concentration) for the in vitro culture of the epiphytic orchid species Dendrobium nobile Lindl. and Dendrobium phalaenopsis Fitzg in asymbiotic media for increased germination and early seedling development.

\section{Results and discussion}

\section{Effects of light and culture media on the germination and} early development of Dendrobium seedlings.

The percentage germination rates (\%Gs) of $D$. nobile and $D$. phalaenopsis were affected by both the light and culture media, as individual factors $(p<0.01)$ and as combined factors $(p<0.01)$. The seeds of both species germinated under all light conditions and using all four types of culture media. The overall mean $\% \mathrm{G}$ for $D$. nobile and $D$. phalaenopsis was $50.6 \%$ and $82.7 \%$, respectively (Table 1 ), supporting the notion that the seeds of these species are neutral photoblastic (Taiz and Zeiger, 2013). Epiphytic orchids are known to be tolerant of dark environments, despite a shortage of water and the scarcity of minerals, which may explain the germination of $D$. nobile and $D$. phalaenopsis seeds in the absence of light (Benzing et al., 1982).

In both orchid species, higher germination rates were observed in the presence of light (16 h), regardless of the culture medium. The average $\% \mathrm{G}$ observed in response to the different types of culture media and in the presence of light was $55.5 \%$ for $D$. nobile and $84.3 \%$ for $D$. phalaenopsis; i.e., respectively $20.0 \%$ (35.5\%) and $6.5 \%$ (77.8\%) higher than those recorded for the same species maintained in continuous darkness $(0 \mathrm{~h})$ (Table 1$)$. Similar results were confirmed by Parthibhan et al. (2012), who studied the effects of different photoperiods on the germination of Dendrobium aqueum Lindl., and found that 46 days after inoculation, the $\% \mathrm{G}$ was only $50.8 \%$ in seeds maintained in continuous darkness but ranged from $67.9 \%$ to $93.9 \%$ as the light exposure increased from 8 to $24 \mathrm{~h}$, respectively.

In the present study, the $\% \mathrm{G}$ of the two species varied in response to the different types of culture media and depending on the light conditions. For $D$. nobile seeds, the $\% G$ was statistically similar in all culture media when seeds were exposed to WF light, with an average germination rate of $57.3 \%$. When seeds were exposed to R and RW light or kept in the dark, the $\% \mathrm{G}$ was higher in MS and $1 / 2 \mathrm{MS}$ media (Table 1). When the seeds of $D$. phalaenopsis were exposed to WF light, the \%G was statistically higher for MS medium than for the other media. Under $\mathrm{R}$ light and continuous darkness (D), the \%G was higher for seeds cultured in MS and $1 / 2$ MS media, whereas under RW light conditions, the $\% G$ was higher when MS, $1 / 2 \mathrm{MS}$, and VW media were used (Table 1).

While some orchid species have been shown to germinate better in culture media that contains high concentrations of nutrients, others require nutrient-poor media for germination (Stewart, 1989). In the present study, \%G was generally higher in both species when cultured with $\mathrm{MS}$ and $1 / 2$ MS media (58.4\% and $60.9 \%$ for D. nobile and $90.2 \%$ and $87.9 \%$ for $D$. phalaenopsis, respectively), than when cultured with VW and K media. Thus, the data obtained in this study corroborate the findings of Lo et al. (2004), who reported that $\mathrm{K}$ and $\mathrm{VW}$ media are less effective than MS and $1 / 2 \mathrm{MS}$ media in promoting germination in Dendrobium tosaense Makino. Regarding the effect of light conditions, the \%G was higher when seeds were cultured under WF and RW light conditions $(57.3 \%$ and $57.4 \%$ for D. nobile and 84.9 and $86.5 \%$ for $D$. phalaenopsis, respectively) (Table 1 ).

Forty-five days after inoculation, the seedlings and protocorms were larger when cultured in MS and $1 / 2 \mathrm{MS}$ media. However, we found seedlings at different stages of development in all media (Figure 1). Seedlings were classified as described by Suzuki et al. (2009), into stage 2 (seedlings with the first leaf formed), stage 3 (seedlings with two leaves), and stage 4 (seedlings with leaves and one or more roots). Under $D$, stage 1 protocorms (protocorm-like bodies) were observed to have germinated 45 days after inoculation. A visual assessment of these protocorms revealed that they were predominantly elongated in shape and that their color was notably white (Figure 1). This latter observation is consistent with the findings that the differentiation of proplastids into chloroplasts and chlorophyll synthesis are light-dependent processes (Taiz and Zeiger, 2013). These results confirm that light is essential for the early stages of growth and development of the two orchid species.

Red light is known to play an important role in the elongation of buds and stems, the promotion of phytochrome responses during photomorphogenesis, and changes in plant anatomy (Shin et al., 2008; Taiz and Zeiger, 2013). In the present study, red light wavelengths promoted the development of seedlings, which reached more advanced stages of early seedling development (stages 3 and 4; Figure 1). These findings indicate that red light is effective 
for the promotion of the growth and development of these two orchid species.

\section{Effects of agar, charcoal, and culture media on the germination and early development of Dendrobium seedlings.}

Dendrobium species vary in their nutritional requirements for germination (Silva et al., 2015). The $\% \mathrm{G}$ of both D. nobile and $D$. phalaenopsis varied according to the type of culture medium and as a function of agar and charcoal concentrations (Figures 2 and 3). However, their mean values were, in some cases, statistically similar (Table 2). Agar, charcoal, and the type of culture medium significantly affected the \%G of both $D$. nobile and $D$. phalaenopsis, as individual factors $(p<0.01)$ and as combined factors $(p<$ 0.01 ) (with the exception of the effect of charcoal on $D$. phalaenopsis). The mean germination rate of $D$. nobile was $71.3 \%$, while that of $D$. phalaenopsis was $92.6 \%$. The highest germination rates were obtained using MS, $1 / 2 \mathrm{MS}$, and $\mathrm{K}$ media for $D$. nobile (statistically similar) and $\mathrm{MS}, 1 / 2 \mathrm{MS}$, and VW media for $D$. phalaenopsis (statistically similar) (Table 2). For $D$. nobile, the highest values for \%G were obtained in MS and VW media supplemented with $6.0 \mathrm{~g} \mathrm{~L}^{-1}$ charcoal and were lower for charcoal concentrations ranging between 0.0 $\mathrm{g} \mathrm{L}^{-1}$ and $0.5 \mathrm{~g} \mathrm{~L}^{-1}$ in $\mathrm{MS}, \mathrm{VW}$, and $\mathrm{K}$ media (Figure 2). In $D$. phalaenopsis, the values for $\% \mathrm{G}$ were higher in agar concentrations of up to $0.5 \mathrm{~g} \mathrm{~L}^{-1}$ in $\mathrm{VW}, \mathrm{MS}$, and $1 / 2 \mathrm{MS}$ media, and lower in agar concentrations above $5.0 \mathrm{~g} \mathrm{~L}^{-1}$ in all culture media (Figure 3 ).

The results of the present study confirmed the successful germination of $D$. nobile and $D$. phalaenopsis in all compositions of culture media. In contrast, Soares et al. (2012) reported the asymbiotic germination of the orchid Brassavola tuberculata Hook. only in culture medium supplemented with activated charcoal.

Similar to the findings of Hossain et al. (2008), where activated charcoal increased germination in the epiphytic orchid Epidendrum ibaguense Kunth, the germination of $D$. nobile increased following the addition of $6.0 \mathrm{~g} \mathrm{~L}^{-1}$ activated charcoal to the culture media (Figure 2). These authors surmised that the high adsorption affinity of activated charcoal for excessive and inhibitory compounds, as well as the darkening of the culture media, promoted the germination process.

In the present study, the highest values of $\% \mathrm{G}$ were generally obtained for both species when a liquid medium was used. According to Faria et al. (2012), liquid media lead to higher \% $\mathrm{G}$ by promoting the diffusion of nutrients to the seeds to a greater extent than solidified media. Furthermore, it is important to highlight that the use of MS and $1 / 2 \mathrm{MS}$ liquid media (supplemented with $0.0 \mathrm{~g} \mathrm{~L}^{-1}$ charcoal and up to $2.0 \mathrm{~g} \mathrm{~L}^{-1}$ agar) appeared to delay seedling development in the present study. Under these conditions, we observed protocorms (protocorm-like bodies) in stage 1 and seedlings (the first leaf formed) in stage 2 according to the classification proposed by Suzuki et al. (2009). In contrast, in MS and $1 / 2$ MS supplemented with more than 4.0 $\mathrm{g} \mathrm{L}^{-1}$ agar (semisolid medium), the seedlings reached a more advanced stage of development, usually stage 3 (two leaves) (Figures 4 and 5).

These findings demonstrated that solidified media was essential for the initial culture of the study species, as media with low concentrations of agar might hinder the establishment of the seedlings (Faria et al., 2012), which could in turn delay their growth and development.

Although the use of $6.0 \mathrm{~g} \mathrm{~L}^{-1}$ of charcoal yielded higher \%G for both $D$. nobile and $D$. phalaenopsis in the MS medium, the addition of charcoal delayed the growth and development of protocorms and seedlings, which were visibly smaller (i.e., did not surpass stages 1 and 2 of development). In contrast, the same medium without charcoal favored larger and more developed seedlings, which were classified as having reached stages 2 and 3 (Figures 4 and 5). In general, activated charcoal is added to culture media at concentrations of $0.2-3.0 \%$ (Faria et al., 2012; Cid and Teixeira, 2014). According to Pasqual et al. (1997), although charcoal itself is not a growth regulator, its presence modifies the compositions of culture media, and thus promotes or inhibits in vitro growth in a species- and tissue-specific manner.

According to Thomas (2008) and Guson et al. (2012), activated charcoal can also affect the absorption of vitamins, metal ions, and growth regulators. In addition, activated charcoal has the ability to retain both growth-inhibiting and growth-promoting substances, slow down their release, and thus ultimately have a positive or negative effect on development, depending on the species. The adsorption promoted by charcoal may also lead to the retention of ions, such as $\mathrm{Cu}$ and $\mathrm{Zn}$, present in the medium (Cid and Teixeira, 2014). As $\mathrm{Zn}$ plays an important role in the metabolism of plant growth, some authors suggest that the increased availability of this nutrient in the culture medium is necessary to improve the growth of different species (Figueiredo et al., 2007; Villa et al., 2014).

Villa et al. (2014) observed that increased concentrations of activated charcoal in $\mathrm{K}$ medium had a negative effect on the leaf morphogenesis of Brassocattleya Pastoral $\times$ Laeliocattleya Amber Glow. These authors attributed this effect to the combination of a solid medium (which inhibits the diffusion of phosphorous, potassium, and zinc) with high concentrations of activated charcoal. This association might have inhibited leaf formation owing to a lack of these elements, which are required for organ formation. Galdiano Júnior et al. (2012) also reported the negative effects of adding charcoal to a culture medium (e.g., the removal of organic nutrients and phytohormones from the culture medium, and the inhibition of the growth and morphogenesis of the cultured species). Moreover, Araújo et al. (2006) stated that the non-selective effect of activated charcoal could negatively affect micropropagation. In summary, the variation in the findings obtained with regard to the effect of the use of activated charcoal when culturing different species of the family Orchidaceae appears to be mostly attributed to genotype, the adsorption of some chemical substances and organic compounds, and the release of toxic metabolites in the in vitro culture (Galdiano Júnior et al., 2012; Prizão et al., 2012; Villa et al., 2014).

The results of the two experiments in the present study highlight the importance of research on orchid germination, as it not only broadens our understanding of the two species studied here but also offers insights into how orchids interact with the culture medium. In addition, the present study sheds light on the poorly understood behavioral patterns in this exotic and commercially important family of plants. The influences of light and the formulation and 
Table 1. Germination rates of Dendrobium nobile and Dendrobium phalaenopsis seeds grown in different culture media and under different light treatments.

\begin{tabular}{|c|c|c|c|c|c|}
\hline \multirow[b]{2}{*}{ Light } & \multicolumn{5}{|c|}{ D. nobile seed germination (\%) } \\
\hline & MS & $1 / 2 \mathrm{MS}$ & $\mathrm{K}$ & VW & Mean*1 \\
\hline WF & $58.5 \mathrm{bA}$ & $64.7 \mathrm{aA}$ & $53.5 \mathrm{aA}$ & $52.7 \mathrm{aA}$ & 57.3 \\
\hline $\mathrm{R}$ & $59.2 \mathrm{bA}$ & $64.2 \mathrm{aA}$ & $43.3 \mathrm{bB}$ & $40.8 \mathrm{bB}$ & 51.9 \\
\hline RW & $69.5 \mathrm{aA}$ & $60.3 \mathrm{aA}$ & $50.2 \mathrm{aB}$ & $49.9 \mathrm{aB}$ & 57.4 \\
\hline D & $46.5 \mathrm{cA}$ & $54.2 \mathrm{bA}$ & $22.5 \mathrm{cB}$ & $18.8 \mathrm{cB}$ & 35.5 \\
\hline \multirow[t]{2}{*}{ Mean*2 } & 58.4 & 60.9 & 42.4 & 40.6 & $50.6 * 3$ \\
\hline & \multicolumn{5}{|c|}{ D. phalaenopsis seed germination (\%) } \\
\hline Light & MS & $1 / 2 \mathrm{MS}$ & $\mathrm{K}$ & VW & Mean*1 \\
\hline WF & $94.6 \mathrm{aA}$ & $89.1 \mathrm{aB}$ & $74.6 \mathrm{aD}$ & $81.2 \mathrm{bC}$ & 84.9 \\
\hline $\mathrm{R}$ & 89.4 bA & $88.3 \mathrm{aA}$ & $74.0 \mathrm{aB}$ & $74.7 \mathrm{cB}$ & 81.6 \\
\hline RW & $90.1 \mathrm{bA}$ & $89.6 \mathrm{aA}$ & $76.0 \mathrm{aB}$ & $90.3 \mathrm{aA}$ & 86.5 \\
\hline D & $86.5 \mathrm{bA}$ & $84.7 \mathrm{bA}$ & $69.4 \mathrm{bB}$ & $70.6 \mathrm{~dB}$ & 77.8 \\
\hline Mean*2 & 90.2 & 87.9 & 73.5 & 79.2 & $82.7^{* 3}$ \\
\hline
\end{tabular}

Lowercase letters indicate significantly different means in the column (Tukey's test at $5 \%$ probability).

Uppercase letters indicate significantly different means in the row (Tukey's test at $5 \%$ probability).

WF: white light, R: red light, RW: red light + white light, D: continuous darkness, MS: Murashige and Skoog, 1/2 MS: half strength MS, K: Knudson C, VW: Vacin and Went media.

${ }^{* 1}$ means of rows; ${ }^{* 2}$ means of columns; ${ }^{* 3}$ overall means.

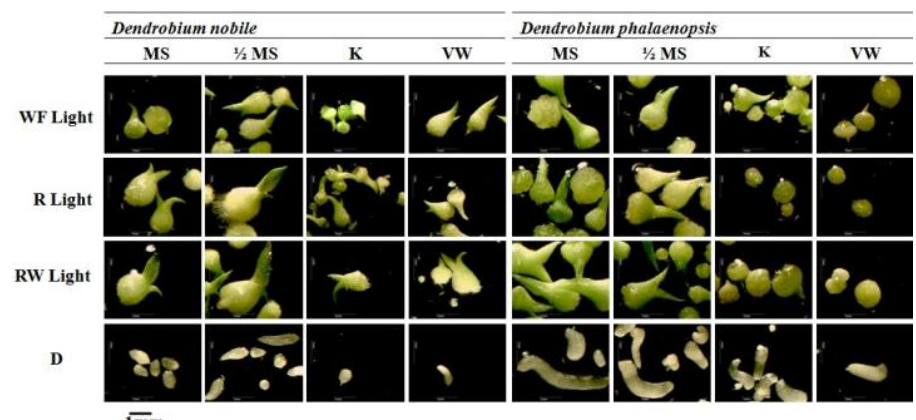

$\sqrt{\mathrm{m} m}$

Fig 1. Seeds, protocorms, and seedlings of Dendrobium nobile and Dendrobium phalaenopsis at 45 days post inoculation in response to different types of culture media and light conditions. WF: white light, R: red light, RW: red light + white light, D: continuous darkness, MS: Murashige and Skoog, $1 / 2$ MS: half strength MS, K: Knudson C, VW: Vacin and Went media.
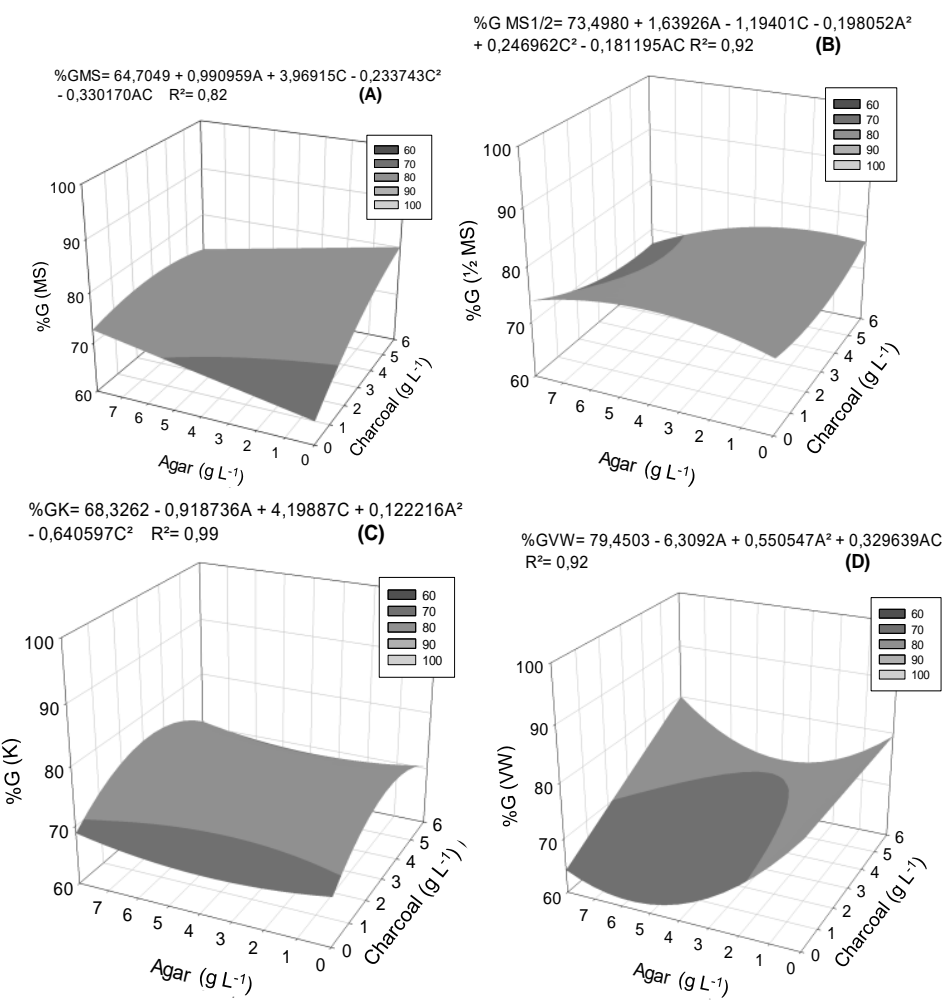

Fig 2. Germination rates (\%G) of Dendrobium nobile seeds in culture media: (A) Murashige and Skoog (MS), (B) half strength MS ( $1 \frac{12}{}$ $\mathrm{MS})$, (C) Knudson $\mathrm{C}(\mathrm{K})$, and (D) Vacin and Went (VW), according to the different concentrations of agar and activated charcoal. 

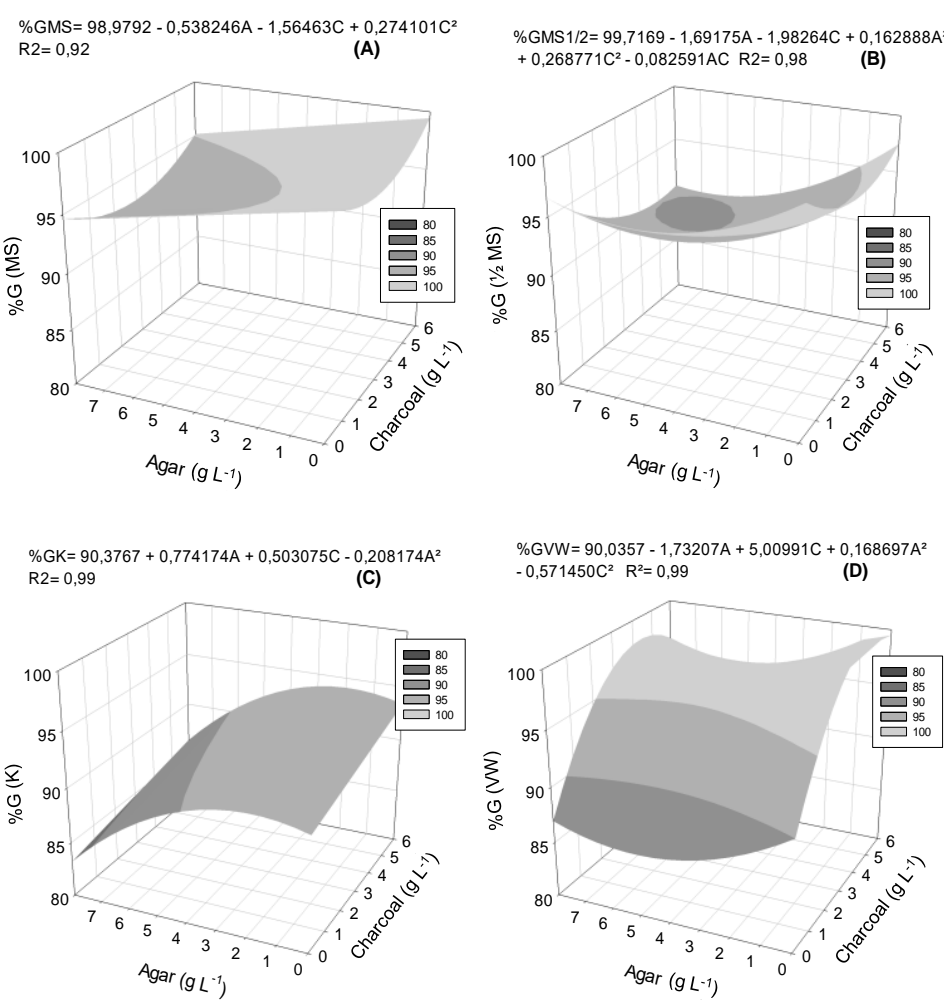

$\% G V W=90,0357-1,73207 \mathrm{~A}+5,00991 \mathrm{C}+0,168697 \mathrm{~A}^{2}$ $\begin{array}{ll}-0,571450 C^{2} R^{2}=0,99 & \text { (D) }\end{array}$

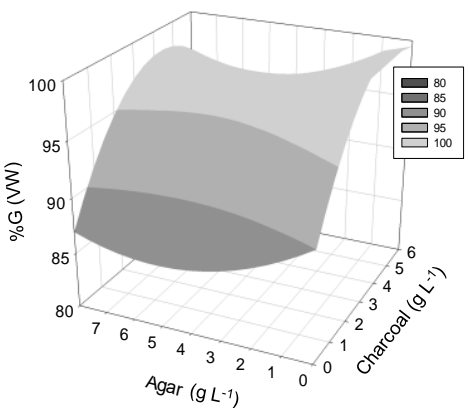

Fig 3. Germination rates $(\% \mathrm{G})$ of Dendrobium phalaenopsis seeds in the culture media: (A) Murashige and Skoog (MS), (B) half strength MS ( $1 / 2 \mathrm{MS}),(C)$ Knudson $C(K)$, and (D) Vacin and Went (VW), according to the different concentrations of agar and activated charcoal.

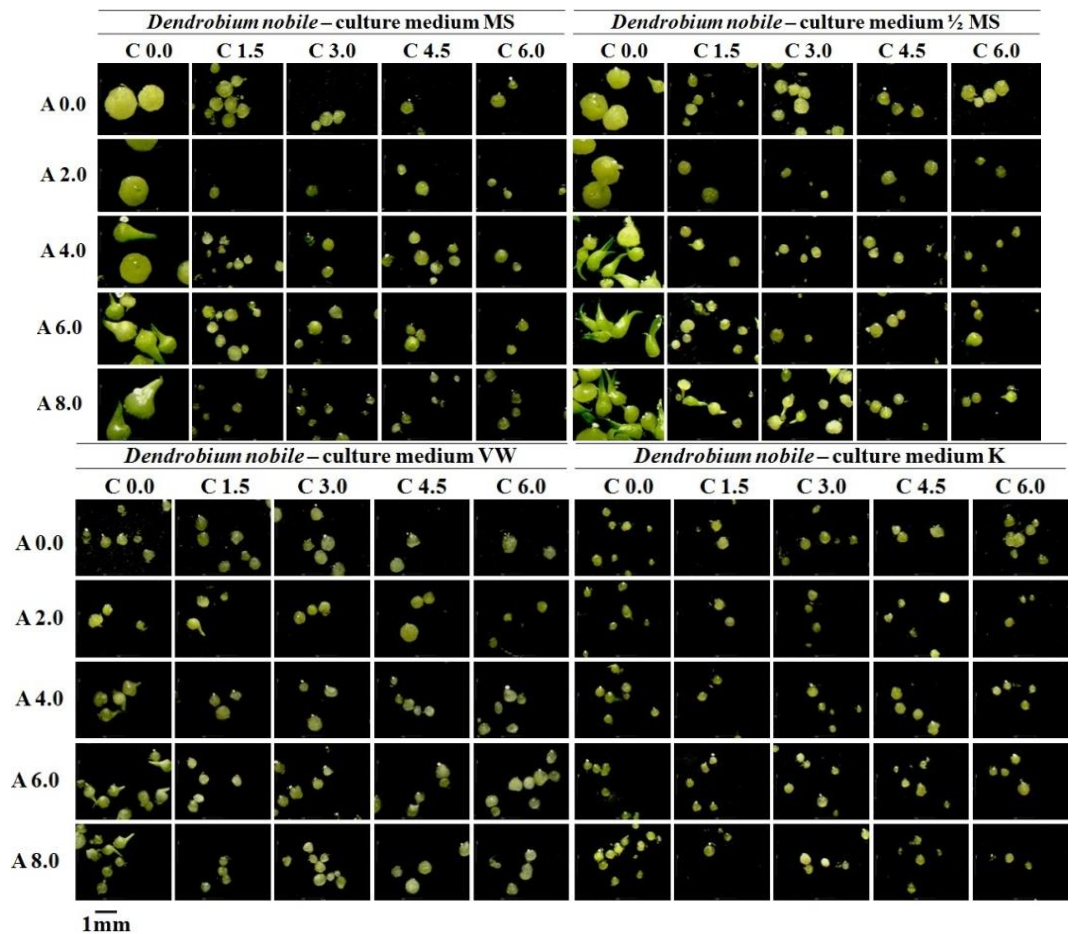

Fig 4. Seeds, protocorms, and seedlings of Dendrobium nobile at 45 days post inoculation in response to different types of culture media, concentrations of agar (A), and activated charcoal (C). MS: Murashige and Skoog, 1/2 MS: half strength MS, K: Knudson C, VW: Vacin and Went media. 

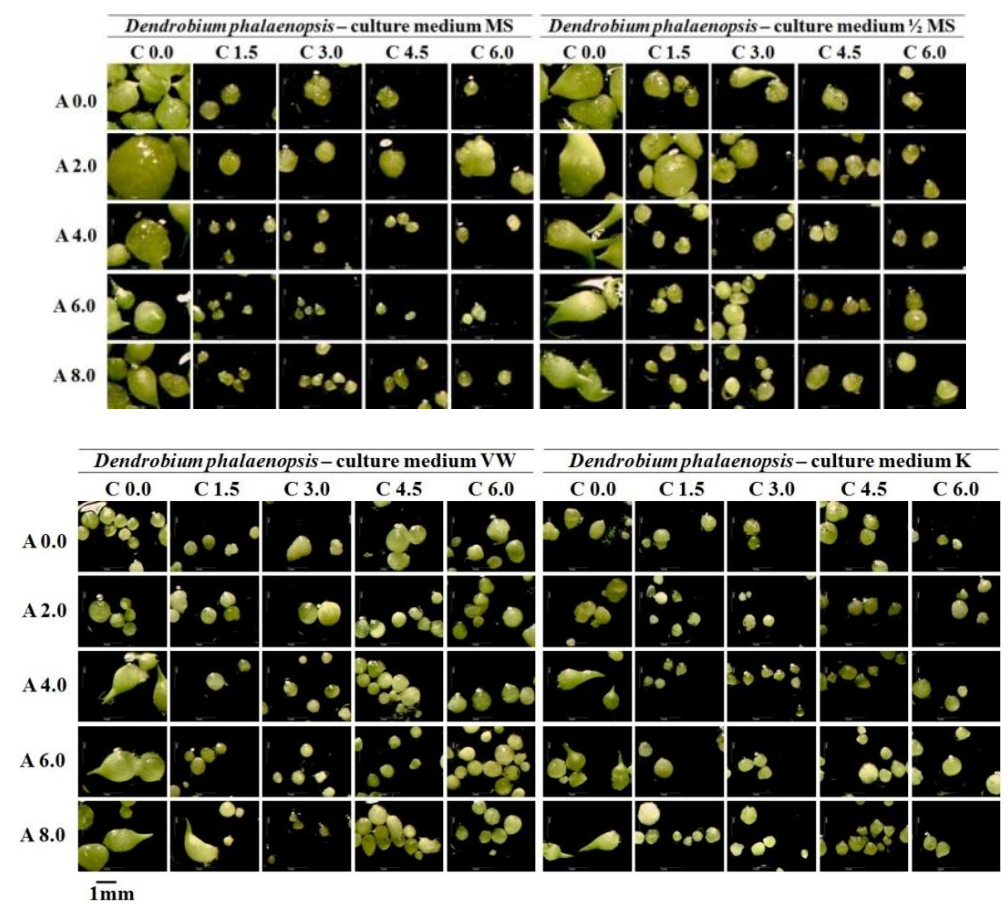

Fig 5. Seeds, protocorms, and seedlings of Dendrobium phalaenopsis at 45 days post inoculation in response to different types of culture media, concentrations of agar (A), and activated charcoal (C). MS: Murashige and Skoog, 1/2 MS: half strength MS, K: Knudson C, VW: Vacin and Went media.

enrichment of culture media at each stage of orchid development should be further elucidated to improve current knowledge and to help establish new protocols in orchid culture.

\section{Materials and methods}

\section{Collection and disinfestation of capsules}

The mature capsules used in this study were collected from hand-pollinated $D$. nobile and $D$. phalaenopsis, which were more than 8 years old. The orchids were cultured in a greenhouse covered by two $50 \%$ shade screens that ensured a daily mean photosynthetically active radiation of $160 \mu \mathrm{mol}$ $\mathrm{m}^{-2} \mathrm{~s}^{-1}$, a mean temperature of $22.6 \pm 5^{\circ} \mathrm{C}$, and a relative humidity of $73.9 \pm 10 \%$. Irrigation was performed using micro-sprinklers.

Capsules were removed from mother plants using pruning shears and transported to the in vitro culture laboratory at the Faculty of Agrarian Science, Federal University of Grande Dourados, Mato Grosso do Sul, Brazil. The capsules were disinfected with $70 \%$ ethanol, and two capsules from each species were opened using a scalpel. The seeds were removed, combined and thoroughly mixed for each species, and then placed in a desiccator with silica gel $\left(25 \pm 2^{\circ} \mathrm{C} ; 75 \%\right.$ relative humidity) for 14 days. After desiccation, the seeds of each species were wrapped in aluminum foil and stored at 5 $\pm 2^{\circ} \mathrm{C}$ in opaque polypropylene bottles with lids.

\section{Seed viability test}

A tetrazolium test was performed for both species according to the methods of Soares et al. (2014). Once seed viability was confirmed, $35 \mathrm{mg}$ of seeds were weighed for each species. The seeds were placed in an aseptic environment and disinfected by immersion in $105 \mathrm{~mL}$ of $0.8 \%$ sodium hypochlorite for $5 \mathrm{~min}$. Seed suspensions were subsequently diluted in sterile distilled water to a total volume of $350 \mathrm{~mL}$ and then rinsed three times with sterile distilled water ( 280 $\mathrm{mL}$ per wash). After washing, seeds were suspended again in $350 \mathrm{~mL}$ of sterile distilled water for in vitro seeding. The inoculation was performed by adding $1000 \mu \mathrm{L}$ of seed suspension to each flask using an automatic pipette.

To achieve the objectives of this study, two independent experiments were designed: (1) light + culture media and (2) culture media + agar concentration + activated charcoal concentration, as follows:

\section{Effects of light and culture media on germination and early seedling development}

\section{In vitro seeding}

The culture media used for seed germination were MS, $1 / 2$ $\mathrm{MS}, \mathrm{VW}$, and $\mathrm{K}$. Culture media were solidified with $4.0 \mathrm{~g} \mathrm{~L}^{-1}$ of bacteriological agar (HiMedia Laboratories, Mumbai, India) and supplemented with $30 \mathrm{~g} \mathrm{~L}^{-1}$ of sucrose. The $\mathrm{pH}$ of each medium was adjusted to 5.8 using $\mathrm{HCl}(0.1 \mathrm{M})$ or $\mathrm{KOH}$ (0.1M). Twenty milliliters of each culture medium were poured into $50 \mathrm{~mL}$ polypropylene bottles with screw caps (height $=5 \mathrm{~cm}$, mouth diameter $=5 \mathrm{~cm}$ ), and bottles were sterilized in an autoclave at $120^{\circ} \mathrm{C}$ at a pressure of $1 \mathrm{~atm}$ for $20 \mathrm{~min}$. After cooling, the bottles were transferred to a sterile environment.

\section{Experimental treatment conditions}

After inoculation, the cultures were placed in a growth room with a photoperiod of 16-hour light (presence of light) or 0 hour light $\left(D=0.0 \mu \mathrm{mol} \mathrm{m} \mathrm{m}^{-2}\right)$ and controlled temperature 
$\left(25 \pm 2^{\circ} \mathrm{C}\right)$. The cultures that were subjected to a 16 -hour photoperiod were exposed to the following light conditions: WF light $\left(18.9 \mu \mathrm{mol} \mathrm{m} \mathrm{s}^{-1}\right.$ irradiance provided by two white fluorescent lamps of $40 \mathrm{~W}$ each), RW light $\left(14.85 \mu \mathrm{mol} \mathrm{m}{ }^{-2}\right.$ $\mathrm{s}^{-1}$ irradiance provided by a white fluorescent lamp of $40 \mathrm{~W}$ and a red fluorescent lamp of $30 \mathrm{~W}$; Gro-lux, Sylvania, Brazil), and $R$ light $\left(9.45 \mu \mathrm{mol} \mathrm{m}{ }^{-2} \mathrm{~s}^{-1}\right.$ irradiance provided by two red fluorescent lamps of $30 \mathrm{~W}$; Gro-lux, Sylvania, Brazil).

\section{Experimental evaluation}

The $\% G$ and early seedling development for each species were determined 45 days after seeding. The seedlings contained in the bottles were rinsed with $3 \mathrm{~mL}$ of sterile distilled water and placed on acrylic plates $(2.0 \times 2.0 \times 0.5$ $\mathrm{cm}$ ) with a $0.5 \times 0.5 \mathrm{~cm}$ square grid. The numbers of nongerminated seeds (NS) and chlorophyll propagules (CP) were determined using a binocular stereomicroscope with transmitted and reflected lights (Bel Photonics, Brazil). The $\% \mathrm{G}$ was calculated using the following equation:

$\% G=\left[\frac{C P}{(N S+C P)}\right] \times 100$.

Early seedling development was evaluated according to the staging scheme of Suzuki et al. (2009). After counting, the treatments were photographed using a digital camera coupled to a stereomicroscope and analyzed using the AxionVision software, version 3.1 (Carl Zeiss, Jena, Germany).

\section{Experimental design and statistical analyses}

A complete randomized experimental design was implemented, with treatments arranged in a split-plot scheme. The plots were each treated with one of four light conditions, and one of the four types of culture media were assigned to each of the sub-plots. Four replications, each represented by a single culture bottle, were prepared per treatment. The results of the $\% \mathrm{G}$ were transformed to $\sqrt{(X+1)}$, subjected to an analysis of variance, and compared using Tukey's test at $5 \%$ probability. The statistical analyses were conducted using SISVAR v.5.3. (Federal University of Lavras, MG, Brazil).

Effects of agar, charcoal, and culture media on seed germination and early seedling development

\section{Experimental treatment conditions and in vitro seeding}

The four types of culture media: MS, $1 / 2 \mathrm{MS}, \mathrm{VW}$, and $\mathrm{K}$, were prepared following the afore mentioned protocols with the exception that, after adding sucrose, the media were supplemented with $0.0,1.5,3.0,4.5$, or $6.0 \mathrm{~g} \mathrm{~L}^{-1}$ activated charcoal and solidified by adding $0.0,2.0,4.0,6.0$, or $8.0 \mathrm{~g}$ $\mathrm{L}^{-1}$ agar. After the polypropylene bottles containing the various media were sterilized as previously described, they were cooled and transferred to a sterile environment for in vitro seeding.

After inoculation, the cultures were placed in a growth room with controlled temperature $\left(25 \pm 2^{\circ} \mathrm{C}\right)$ and photoperiod (16 $h$ light). The ideal light regimes of the two species were designated according to the results obtained in the first experiment, and thus $D$. nobile seeds and seedlings were cultured under WF light and $D$. phalaenopsis seeds and seedlings were cultured under RW light. The \%G and early seedling development were determined following the same protocols outlined in the first experiment.

\section{Experimental design and statistical analyses}

A complete randomized design was used, and treatments were arranged in $4 \times 5 \times 5$ factorial scheme (four culture media, five concentrations of agar, and five concentrations of activated charcoal). Each treatment was replicated three times and each replicate consisted of a single culture bottle. The results of \%G were transformed to $\sqrt{(X+1)}$ and subsequently subjected to an analysis of variance. The qualitative parameters were compared using Tukey's test at $5 \%$ probability and the quantitative parameters were compared via regression analyses using SAEG 9.1 (Arthur Bernardes Foundation, Federal University of Viçosa, MG, Brazil).

\section{Conclusion}

The presence of light and the type of culture medium used in the present study were not the limiting factors in the in vitro germination of the two study orchid species. The highest $\% \mathrm{G}$ and the optimum early seedling development were observed in the presence of WF light for $D$. nobile and RW light for $D$. phalaenopsis in MS and $1 / 2$ MS culture media. MS and $1 / 2$ MS culture media were the most effective in promoting the in vitro germination of $D$. nobile and $D$. phalaenopsis. The use of MS and $1 / 2$ MS culture media solidified with $4.0-8.0 \mathrm{~g} \mathrm{~L}^{-1}$ of agar without activated charcoal is recommended for the optimal development of $D$. nobile and $D$. phalaenopsis seedlings.

\section{Acknowledgments}

The authors thank CAPES and UFGD (Brazil) for the scholarships granted, for technical and financial assistance, and specially Dr. Yara Brito Chaim Jardim Rosa (In memoriam).

\section{References}

Araújo AG, Pasqual M, Pereira A, Rocha H (2006) Crescimento in vitro de Laelia tenebrosa (Orchidaceae) em diferentes concentrações de sais de Knudson $C$ e carvão ativado. Plant Cell Cult Micropropag. 2:53-106.

Arditti J and Ernst R (1984) Physiology of germinating orchid seeds. In: Arditti J Orchid Biology: Reviews and Perspectives III. New York: Cornell University Press. p. 177222.

Benzing DH, Ott DW and Friedman WE (1982) Roots of Sobralia macrantha (Orchidaceae): structure and function of the velamen-exodermis complex. Am J Bot. 69:608-614.

Cid LPB and Teixeira JB (2014) Explante, meio nutritivo, luz e temperatura. In: Cid LPB. Cultivo in vitro de plantas. 3. ed. Brasília: Embrapa Informação Tecnológica. p. 17-45.

Dutra D, Kane M and Richardson L (2009) Asymbiotic seed germination and in vitro seedling development of Cyrtopodium punctatum: a propagation protocol for an endangered Florida native orchid. Plant Cell Tiss Org. 96:235-243. 
Faria RT, Assis AM, Unemoto LK, Carvalho JFRP (2012) Produção de orquídeas em laboratório. Londrina: Mecenas. $124 \mathrm{p}$.

Figueiredo MA, Santos FM, Silva JOC, Costa FHS, Pasqual M (2007) Variações no meio de cultura sobre o crescimento in vitro em híbridos de orquídea. $\mathrm{R}$ Bras Bioci. 5:294-296.

Galdiano Júnior RF, Mantovani C, Pivetta KFL, Lemos EGM (2012) Crescimento in vitro e aclimatização de Cattleya loddigesii Lindley (Orchidaceae) com carvão ativado sob dois espectros luminosos. Cienc Rural. 42:801-807.

Godo T, Komori M, Nakaoki E, Yukawa T, Miyoshi K (2010) Germination of mature seeds of Calanthe tricarinata Lindl., an endangered terrestrial orchid, by asymbiotic culture in vitro. In Vitro Cell Dev-PI. 46:323-328.

Guson RR, Moraes CP and Ronconi CC (2012) Influência de diferentes concentrações de carvão ativado no crescimento e enraizamento in vitro de Cattleya pumila Hook. Rev Agro Amb. 5:551-563.

Hossain MM (2008) Asymbiotic seed germination and in vitro seedling development of Epidendrum ibaguense Kunth. (Orchidaceae). Afr J Biotechnol. 7:3614-3619.

Kauth PJ, Kane ME, Vendrame WA, Reinhardt-Adams C (2008) Asymbiotic germination response to photoperiod and nutritional media in six populations of Calopogon tuberosus var. tuberosus (Orchidaceae): evidence for ecotypic differentiation. Ann Bot. 102:783-793.

Knudson L (1922) Non-symbiotic germination of orchid seeds. Bot gaz. 73:1-25.

Knudson $L$ (1946) A new nutrient solution for germination of orchid seeds. AOSB. 15:214-217.

Kitsaki CK, Zygouraki S, Ziobora M, Kintzios S (2004) In vitro germination, protocorm formation and plantlet development of mature versus immature seeds from several Ophrys species (Orchidaceae). Plant Cell Rep. 23:284-290.

Lee YI, Lu FL, Yeung EC, Chung MC (2007) Developmental change in endogenous abscisic acid concentrations and asymbiotic seed germination of a terrestrial orchid, Calanthe tricarinata Lindl. J Am Soc Hortic Sci. 132:246252.

Lo SH, Nalawade SM, Kuo CL, Chen CL, Tsay HS (2004) Asymbiotic germination of immature seeds, plantlet development and ex vitro establishment of plants of Dendrobium tosaense Makino - a medicinally important orchid. In Vitro Cell Dev-PI. 40:528-535.

Murashige TA and Skoog FA (1962) A revised medium for rapid growth and bioassays with tobacco tissue culture. Physiol Plant. 15:473-497.

Parthibhan S, Benjamin JHF, Muthukumar M, Sherif NA, Senthil KT, Rao MV (2012) Influence of nutritional media and photoperiods on in vitro asymbiotic seed germination and seedling development of Dendrobium aqueum Lindley. Afr J Plant Sci. 6:383-393.

Pasqual M, Hoffmann A and Ramos JD (1997) Cultura de tecidos: tecnologia e aplicações - introdução: fundamentos básicos. Lavras: UFLA/FAEPE. $159 \mathrm{p}$.

Paul S, Kumaria S and Tandon P (2012) An effective nutrient medium for asymbiotic seed germination and large-scale in vitro regeneration of Dendrobium hookerianum, a threatened orchid of northeast India. AoB Plants. 2012:112.
Prizão EC, Gonçalves LDM, Gutierre MAM, Mangolin CA, Machado MDFPD (2012) Activated charcoal and graphite for the micropropagation of Cattleya bicolor Lindl. and a orchid double-hybrid 'BLC Pastoral Innocence'. Acta SciAgron. 34:157-161.

Shin KS, Murthy HN, Heo JW, Hahn EJ, Paek KY (2008) The effect of light quality on the growth and development of in vitro cultured Doritaenopsis plants. Acta Physiol Plant. 30:339-343.

Silva JAT, Tsavkelova EA, Ng TB, Parthibhan S, Dobránszki J, Cardoso JC, Rao MV, Zeng S (2015) Asymbiotic in vitro seed propagation of Dendrobium. Plant Cell Rep. 34:1685-1706.

Soares JS, Rosa YBCJ, Suzuki RM, Scalon SPQ, Rosa Junior EJ (2012) Germinação assimbiótica e desenvolvimento de Dendrobium nobile Lindl. sob efeito de reguladores vegetais no tratamento pré-germinativo. Rev Bras PI Med. 14:617-623.

Soares JS, Rosa YBCJ, Tatara MB, Sorgato JC, Lemes CSR (2014) Identificação da viabilidade de sementes de orquídeas pelo teste de tetrazólio. Semin-Cienc Agrar. 35:2275-2284.

Stewart J (1989) Orchid propagation by tissue culture techniques - past, present and future. In: Pritchard HW. Modern methods in orchid conservation: the role of physiology, ecology and management. Cambridge: Cambridge University Press. p. 87-100.

Stewart SL and Kane ME (2006) Asymbiotic seed germination in vitro seedling development of Habenaria macroceratitis (Orchidaceae), a rare Florida terrestrial orchid. Plant Cell Tiss Org. 86:147-158.

Stoutamire W (1974) Terrestrial orchid seedling. In: Withner CL. The orchids: Scientific studies. New York: WileyInterscience. p. 101-128.

Suzuki RM, Almeida V, Pescador R, Ferreira WM (2010) Germinação e crescimento in vitro de Cattleya bicolor Lindley (Orchidaceae). Hoehnea. 37:731-742.

Suzuki RM, Moreira VC, Nacabashi M, Ferreira WM (2009) Estudo da germinação e crescimento in vitro de Hadrolaelia tenebrosa (Rolfe) Chiron \& V. P. Castro (Orchidaceae), uma espécie da flora brasileira ameaçada de extinção. Hoehnea. 36:657-666.

Taiz L and Zeiger E (2013) Fisiologia Vegetal, 5. ed. Porto Alegre: Artmed. $954 \mathrm{p}$.

Thomas TD (2008) The role of activated charcoal in plant tissue culture. Biotechnol Adv. 26:618-631.

Tsutsumi C, Miyoshi K, Yukawa T, Kato M (2011) Responses of seed germination and protocorm formation to light intensity and temperature in epiphytic and terrestrial Liparis (Orchidaceae). Botany. 89:841-848.

Vacin EF and Went FW (1949) Some pH in nutrient solutions. Bot gaz. 110:605-613.

Villa F, Pasqual M and Silva EF (2014) Micropropagação de híbridos de orquídea em meio Knudson com adição de vitaminas do meio MS, benzilaminopurina e carvão ativado Semin-Cienc Agrar. 35:683-694.

Yamazaki J and Miyoshi K (2006) In vitro asymbiotic germination of immature seed and formation of protocorm by Cephalanthera falcata (Orchidaceae). Ann Bot-London. 98:1197-1206. 